Article

\title{
Embedding Sustainability in the Economics Degree of the Faculty of Economics and Business of the University of Murcia: A Methodological Approach
}

\author{
Lourdes Molera *, Eugenio José Sánchez-Alcázar, Úrsula Faura-Martínez (), Matilde Lafuente-Lechuga (),

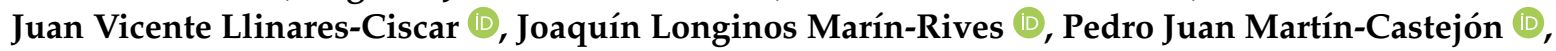 \\ María Carmen Puigcerver-Peñalver and María C. Sánchez-Antón
}

check for

updates

Citation: Molera, L.;

Sánchez-Alcázar, E.J.; Faura-Martínez,

Ú.; Lafuente-Lechuga, M.;

Llinares-Ciscar, J.V.; Marín-Rives, J.L.;

Martín-Castejón, P.J.

Puigcerver-Peñalver, M.C.;

Sánchez-Antón, M.C. Embedding Sustainability in the Economics

Degree of the Faculty of Economics and Business of the University of

Murcia: A Methodological Approach. Sustainability 2021, 13, 8844. https:// doi.org/10.3390/su13168844

Academic Editors:

Fermin Sanchez-Carracedo,

Jordi Segalàs Coral and

Gemma Tejedor

Received: 30 June 2021

Accepted: 4 August 2021

Published: 7 August 2021

Publisher's Note: MDPI stays neutral with regard to jurisdictional claims in published maps and institutional affiliations.

Copyright: (C) 2021 by the authors Licensee MDPI, Basel, Switzerland. This article is an open access article distributed under the terms and conditions of the Creative Commons Attribution (CC BY) license (https:// creativecommons.org/licenses/by/ $4.0 /)$.
Faculty of Economics and Business, University of Murcia, 30100 Murcia, Spain; eugenioj@um.es (E.J.S.-A.); faura@um.es (Ú.F.-M.); mati@um.es (M.L.-L.); llinares@um.es (J.V.L.-C.); longinos@um.es (J.L.M.-R.); pjmartin@um.es (P.J.M.-C.); mcpuig@um.es (M.C.P.-P.); csanchez@um.es (M.C.S.-A.)

* Correspondence: lmolera@um.es; Tel.: +34-868883781

Abstract: Education has been traditionally considered as a means to promote and disseminate sustainable development through the reorientation of the curriculum towards sustainability at all levels of the educational system. Higher Education Institutions take a leading role in this process. However, they face several limitations, including their lack of training in the topic, which is complex and difficult to fit into disciplines to begin with. This paper presents the experience of the Working Group on Curricular Sustainability of the Faculty of Economics and Business of the University of Murcia (Spain), carried out within the framework of a pilot project of teaching innovation whose objective was the incorporation of sustainability in the Degree in Economics. In doing so, a Sustainability Competency Map was drawn up and open educational resources that enable students to acquire these competencies were developed.

Keywords: sustainability; higher education; open educational resources; competencies in sustainability; sustainable development goals; sustainability competency map; education for sustainable development

\section{Introduction}

According to the UN (See https:/ / public.wmo.int/en/media/news/2021-"make-orbreak-year" -climate-action, accessed on 30 July 2021, based in the report The State of the Global Climate 2020, by the World Metereological Organization), 2019 was the second hottest year ever recorded and marked the end of the hottest decade (2010-2019) ever recorded. A $45 \%$ reduction in greenhouse gas emissions is needed by 2030 to avoid catastrophic warming. However, at present, countries are only willing to cut emissions by $1 \%$. UN climate change experts are calling for immediate action and specific plans to address the emergency.

Solving this problem, as well as other major social and economic challenges, involves not only mobilising large amounts of economic resources, but also raising awareness and educating society as a whole in order to understand the implications for human life on the planet if this is not achieved. In particular, according to previous studies, awareness of sustainability is rather low in the teenage years [1] and therefore, young people enter higher education with little knowledge and concern for this issue, hence the important role of universities in training and raising awareness of Sustainable Development (SD) among future professionals. Following the Rio+20 summit, several authors such as $[2,3]$ have called for the inclusion of sustainability in most university activities as a mechanism to ensure the training of students in sustainable development. In that regard, Boeve-de Pauw et al. [4] demonstrated that education for sustainable development impacts student outcomes in terms of their sustainability consciousness. 
As a follow-up to the World Summit on Sustainable Development held in Johannesburg in 2002, the United Nations General Assembly adopted the resolution of the United Nations Decade of Education for Sustainable Development (ESD), which was ratified by UNESCO in April 2003. It includes in its programme the central role of education as a way to achieve sustainable development and highlights the need to reorient the curriculum towards sustainability. The main objective of the ESD Decade is specified in section II, heading 5 of UNESCO's own document: "to promote education as a basis for a more sustainable human society and to integrate sustainable development into education systems at all levels" [5]. Some authors warn that many universities are becoming more market-oriented and, therefore, consumer-centric policies and increased industry involvement in curricula are gaining more attention than sustainability pedagogy [6]. This trend led authors such as Lozano et al. [7] to call for integral implementation of sustainability, meaning that such sustainability should become apparent in most, if not all, university activities as a mechanism to ensure education for sustainable development.

In this context, the professional development of teachers in education for sustainable development (ESD) has been considered as the priority of priorities. In fact, as Ferreira [8] said, UNESCO has insisted in recent years on the need to reorient teacher education towards sustainability [5,9-12] and make them facilitators of ESD.

To this end, the University of Murcia (Spain) has implemented a two-year project called ODSesiones [13], whose aim is two-fold. First, it intends to increase awareness of the Sustainable Development Goals (SDG) among university members and, second, it wants to exert an effective social impact by promoting intervention activities proposed by non-governmental organisations (NGO) and schools. As a result, more favourable attitudes towards the SDGs and a behavioural change among university members, and citizens in general, is expected [14].

As part of ODSesiones, the general objective of the so-called Aula 2030 programme (2030 Classroom) [15] is to create an interactive space where experts, professors, and students are given the opportunity to discuss the way of embedding sustainability into the curricula. So far, its main line of work is teacher training on sustainability, which has led to the organisation of nine introductory courses on Curricular Sustainability and two advanced courses.

In a parallel way, encouraged by Aula 2030 principles on sustainable education, a group of lecturers from different areas of knowledge in the Faculty of Economics and Business of the University of Murcia participated, over the last two years, in a methodological proposal for the implementation of Curricular Sustainability in the Bachelor's Degree in Economics. Their aim was to initiate a process of change focused on an education oriented towards the principles of sustainable development, with the intention of extending it to the rest of the degrees in the Faculty. The work began as a pilot project within the framework of teaching innovation, where one of its expected results is the implementation of a trainers training programme. This pilot project, entitled "Elaboración de mapas de sostenibilidad, contenidos transversales básicos en sostenibilidad e instrumentos para la sostenibilización curricular en la Facultad de Economía y Empresa" ("Development of sustainability maps, basic cross-cutting content in sustainability and tools for curricular sustainability in the Faculty of Economics and Business"), ran from 12 November 2019 to 30 September 2020, although the Working Group has continued to be involved in initiatives related to curricular sustainability. The project objectives were: to design a sustainability map of the Economics degree; to associate competency learning outcomes with the SDGs; to identify and to elaborate contents in sustainability for each of the dimensions used in the sustainability map (economic, social, environmental, and holistic); and to diagnose the state of training needs in sustainability in teachers and develop and test training proposals.

This training programme is currently in progress as a part of the Aula 2030, whose staff includes several members of the Curricular Sustainability Working Group of the Faculty of Economics and Business. The main instrument used to integrate sustainability into the curricula is the so-called Sustainability Competency Map (SCM) [16,17], which is 
based on the SCM for the Bachelor's Degree in Business Administration developed within the EDINSOST project.

The basic sustainability competencies that students should acquire throughout their university education should be agreed when designing the SCM. As the literature review reveals, this is not an easy task, since there is not a general agreement on what the key competencies for sustainability in higher education actually are [18]. In this sense, the strategic role played by the Conference of Chancellors of Spanish Universities (CRUE) has been very convenient to our work, since the Conference agreed upon them in the document entitled Guidelines for the Inclusion of Sustainability in the Curriculum [19]. Consequently, we decided to apply the competency approach in this paper because of CRUE's role on building the capacities and competencies on curricular sustainability carried out in Spanish universities. To work on these competencies, we provided a variety of Open Educational Resources (OER), a format in line with the UNESCO guidelines, which state that "universal access to quality education is fundamental for the construction of peace, sustainable social and economic development, as well as intercultural dialogue" [20].

Therefore, this article aimed to contribute to the existing literature on the embedding of sustainability in Higher Education Institutions (HEIs) by sharing the experience of the Faculty of Economics and Business at the University of Murcia. This experience is based on the use of the SCM as the fundamental instrument for integrating sustainability in the curriculum, which implied two main tasks: the adaptation of the degree of the Business Administration SCM to the curricular contents of the Economics Degree and the development of a wide range of learning resources in line with the UNESCO guidelines [20] to be applied in the classroom by teachers.

In summary, this work will help to deepen the contribution of SCM and the OERs to the teaching-learning process; it will also serve as a starting point for embedding sustainability in other degrees, especially those related to Social Sciences, which can be of great interest for other researchers.

This article contextualises our work within the existing literature on Curricular Sustainability in Section 2. Section 3 describes the methodology followed for the development of the SCM and the OERs. Subsequently, Section 4 reviews the OERs developed, while Sections 5 and 6 are devoted to the discussion of the results and conclusions.

\section{Literature Review}

In this section, we are concerned with covering four main issues: changes in HEIs to address education for sustainable development; the importance of teacher training in embedding sustainability in the curricula; the competencies approach; and the design of educational resources that facilitate teachers' integration of sustainability in the curriculum.

\subsection{Changes in Higher Education Institutions}

Over the last three decades, HEIs have mobilised to integrate sustainable development into their traditional roles of research and expert education [21] into the so-called third mission of knowledge and technology transfer [22], and into any other campus activity $[23,24]$. UNESCO's role has been particularly relevant through the adoption of the Decade of Education for Sustainable Development (ESD) and its subsequent extensions $[11,12,25,26]$ The adoption in 2015 of the 2030 Agenda with 17 sustainable development goals was the definitive impetus to include education as one of the cross-cutting goals to achieve sustainability [27]. Specifically, goal number 4 refers to "Ensure inclusive and equitable quality education and promote lifelong learning opportunities for all".

Traditionally, the sustainable development approach in the higher education system (as Collazo and Granados mentioned [28], the process of adapting the curriculum towards sustainability has been referred to in different ways: curricular sustainability [19], sustainable curriculum [29], or curriculum reorientation [30]) has been embedded at one of the following levels: (a) research; (b) education; (c) institutional functioning; (d) community outreach; or (e) evaluation and reporting [31,32]. In education, these actions have focused 
on areas such as teaching methodologies that facilitate the embedding of sustainability, the identification and embedding of sustainability competencies in curricula, curricular content, specific teacher training and, in general, all aspects related to the reorientation of the curriculum towards sustainability.

There are organisations, such as the Sustainable Development Solutions Network (SDSN), which do important work in disseminating HEI practices. It is a global initiative of the United Nations that mobilises expertise and resources from academia, civil society, and the private sector, providing solutions for sustainable development at local, national, and global levels [28]. Its publications [33,34] have been an obligatory reference to guide universities' progress towards sustainability based on the SDGs, and offer a compilation of experiences in universities around the world on their way to implementing the 2030 Agenda [35].

Likewise, over the last few years, numerous initiatives have emerged related to the embedding of sustainable development in HEIs through education [2]. Some seek to integrate sustainable development education into the university framework at a general level $[36,37]$, while others propose more concrete solutions. Some examples are the proposals integrated into specific subjects to develop students' professional ESD competencies [38-40] or proposals in which the university management team and teachers can develop professional ESD competencies by integrating sustainability into the curriculum in a concrete way [41]. Other initiatives focus on educator educational programs in sustainability [42,43], or analyse the presence of sustainability in terms of curricular content and competency training for students, teachers, and specific degree curricula [44].

A relatively new area contributing to a growing number of publications is the study of relevance, relationships, and possible strategies for achieving the SDGs in HEIs [45,46]. For instance, the evaluation of activities aimed at graduate students using a holistic rubric that measures their capacity to incorporate sustainability principles [47]; the design of specific courses for professors aimed at guiding the integration of ESD in the curriculum of university subjects [28]; or the provision of a multi-stakeholder framework (faculties, students, NGOs, private companies, public administration, professional associations, trade unions, etc.) for raising awareness among the university community and society in general [14].

\subsection{The Importance of Teacher Training}

However, despite the importance of ESD and its close relationship with higher education, there are still major obstacles to its full integration in HEIs [48-50]. Some authors argue that "it is a concept that has not penetrated enough and has not done so equally, in all university disciplines" [48] or, it is not integrated into universities in a holistic way but compartmentalised, focusing only on some of the domains of sustainability [49]. Lozano [51] argued that ESD is still considered an innovative idea in most universities, and involves the adoption and institutionalisation of new concepts or ideas. However, these new ideas have not yet permeated all disciplines, university faculties, and managers, or throughout curricula. This is due to the existence of three types of barriers: (a) resistance based on lack of information; (b) resistance based on psychological and emotional reaction to change; and, (c) resistance to change due to disciplinary rules [32].

One of the main obstacles is the limited frame of reference and the limited training that teachers themselves have in sustainability, which diverges from UNESCO's proposal on using university teacher training as a key strategy to achieve a sustainable society [9]. In this way, it seems appropriate to sustainability that teachers play a primary role in the implementation of this process and, therefore, teacher training is fundamental to move towards curricular sustainability.

As Lozano [52] points out, "educating educators" is a fundamental element for integrating sustainable development into the university system. It is therefore of utmost importance to identify those professors who are particularly sensitive to curricular sustainability and to direct training primarily to innovators, as they will serve as teachers for the group of laggards, who will be the last to integrate sustainability into their teaching [32]. Ultimately, 
the teacher, being at the centre of curriculum development, should, from the classroom and through the teaching method applied, lead the learning process towards sustainability.

In response to the lack of teacher training, some projects have been launched. At the international level, the University Professors for Sustainable Development (UE4SD) project, launched in 2013 at the University of Gloucestershire and partner institutions, aims to support university staff to improve their ESD skills. The project focuses on establishing professional development approaches and opportunities that enable teachers to prepare students to understand and apply their professional and global responsibilities in sustainability. The project, funded by the European Commission under the Erasmus Academic Networks Lifelong Learning Programme (2013-2016), includes 53 partners from 33 countries across Europe, grouped into four regional centres, and seeks to combine and share the experience of network partners in this area [53].

At the national level, the EDINSOST projects, which are funded by the Spanish State R\&D\&i Programme, have provided important tools for the integration of ESD and the SDGs in HEIs. As stated in [16,17], their main objectives are the embedding of sustainability into the curriculum, the design of teaching and learning strategies for its implementation in the Spanish university context, and the evaluation of the sustainability competency level of current graduates in the Spanish university system.

Thus, the first step in teacher training is to define clearly and accurately the sustainability learning outcomes of each Degree involved in the project, which are precisely defined in the Sustainability Competency Map.

\subsection{The Competency Approach}

A further aspect of learning concerns university students, who should acquire a series of competencies that enable them to develop specific profiles of their academic specialty, which would also provide a benchmark framework for assessing both learning and teaching effectiveness. The sustainability competencies that students should acquire throughout their university education should be central to the design of study programmes. Furthermore, the aim of the teaching staff should be to address the key competencies to enable students to effectively play the role of agents of change when they enter the labour market.

Although there is no agreement on what the key competencies for sustainability in higher education actually are [18], we can define them as the set of knowledge, skills, and attitudes that enable the effective resolution of tasks and problems related to the challenges and opportunities posed by sustainability in the real world $[54,55]$. According to Benito Olalla and Merino [56], the delimitation of competencies for sustainability is given by the four pillars of lifelong learning according to the recommendations of the Delors Report [57] (learning to know, learning to do, learning to live together, and learning to be), to which is added a fifth pillar suggested by UNESCO, namely, learning to transform oneself and society [58]. Moreover, some authors have developed a framework consisting of seven competencies in sustainability in the professional environment: systems thinking competency, foresight competency, normative competency, embracing diversity and interdisciplinary, interpersonal competency, action competency, and strategic management $[59,60]$.

We decided to apply the competency approach in this paper because of the strategic role played by the Conference of Chancellors of Spanish Universities (CRUE) on building the capacities and competencies on curricular sustainability carried out in Spanish universities, where the degrees are designed using competencies.

In [19], the CRUE recognised that higher education is a key tool for achieving SD and that the university should not limit itself to generating disciplinary knowledge, but also to preparing professionals to promote social change, using their knowledge to solve social and environmental needs. This implies progressively introducing new learning strategies that facilitate the student's training in sustainability and that make it possible to tackle the entire educational process in a holistic manner, considering how the student will interact with the economic, social, and environmental surroundings in their professional life. It 
is also important to highlight that curricular sustainability goes beyond the teaching of specific subjects; it involves introducing changes in the entire teaching-learning process, in competencies, methodology, content, assessment, and good practices [61].

As stated in [53], since 2008, the CRUE's Curricula and Sustainability Working Group has been making progress in introducing sustainability into the university curriculum. This group consists of more than 20 universities, each one with a group of people working in this initiative, such as the Curricular Sustainability Working Group of the Faculty of Economics and Business at the University of Murcia. In this context, innovative teaching projects for building sustainability skills are being developed and implemented. One of the main activities is training academic staff, through a Teacher Training Course, Introduction to Sustainability in University Teaching, to be taught at any Spanish university by request.

The group offers a clear consensus on the competencies that should be integrated in all degrees, which were identified and formulated by the CRUE-Sustainability Sector Commission (CSCS). These appear for the first time in the document Guidelines for the Introduction of Sustainability in the Curriculum [19], published in 2005 and updated in 2012:

- C1: Critical contextualisation of knowledge through the linking of social, economic and environmental issues on a local and/or global level.

- C2: Sustainable use of resources and prevention of negative impacts on natural and social environments.

- C3: Participation in community processes that promote sustainability.

- C4: Application of ethical principles related to sustainability values in personal and professional behaviour.

As it will be seen in the next section, based on these four cross-cutting competencies, we built the SCM presented in this paper.

\subsection{Design of Educational Resources}

As mentioned above, the SCM stands out as one of the basic tools for integrating ESD into the university system, as it facilitates the identification of learning outcomes, i.e., what students are expected to know, understand, and be able to do at the end of a learning period [62]. Learning outcomes should be well defined in terms of knowledge, skills, and abilities achieved by the learner at the end of the process as a result of the participation in a particular set of educational experiences [63]. In this context, an appropriately designed set of learning resources would facilitate the student's achievement of these learning outcomes, making it a useful tool.

Currently, there is a wide variety of OERs which are freely available to the educational community. The term was first used in 2002 by UNESCO, referring to "educational resources, enabled by information and communication technologies, for consultation, use and adoption by a community of users for non-commercial purposes" [64]. Subsequently, several definitions have been given that qualify the idea of "open" [64-67], in the sense that they are resources that can be used or reused for teaching and learning, either entirely freely or, more often, under a free intellectual property license that regulates the type of use that can be made of them. A widely accepted definition was provided by UNESCO in 2015: "educational resources that are openly available for use by educators and students, without an accompanying need to pay royalties or license fees" $[68,69]$.

OERs encompass a wide variety of resources, from small pieces of learning support (videos, readings, multimedia applications, illustrations, podcasts, curriculum maps, etc.) to complete courses. Given the increasingly digital society in which we live, they are often associated with digital materials [70]. To encourage the use of these resources, it is advisable to place them in easily accessible repositories [65], and it is recommended that their adaptation be designed with tools that do not involve a very high level of difficulty [66].

OERs are thus a relatively new way of sharing knowledge and improving the quality of teaching and learning, and are very useful for advancing the achievement of Sustainable Development Goal 4 and, in general, for working on the other SDGs [71]. However, 
although its growth has been exponential in recent years, difficulties have also been encountered, such as the lack of involvement of some institutions or groups and the need to update the materials over time [72].

\section{Materials and Methods}

Over the last two years, a group of Faculty of Economics and Business (University of Murcia, Spain) lecturers have participated in the methodological proposal for the implementation of Curricular Sustainability in the Degree in Economics. The work began as a pilot project within the framework of a call of teaching innovation whose final objective was that Economics degree graduates acquired the necessary competencies to make decisions and carry out their professional activities from the perspective of sustainability.

With this aim, in November 2019, a Working Group of 10 associate professors from different branches of knowledge was formed, motivated by and experienced in teaching subjects related to sustainability. Not only the variety of branches of knowledge (Economic Theory, Applied Economics, Quantitative Methods, Business and Marketing, and Corporate Social Responsibility), but also the fact that many of them are involved in the management team of the Faculty of Economics and Business as well as of the University, makes it easier to embed the sustainability in both the faculty and the university. Moreover, four of them are members of the EDINSOST project, which is focused on sustainability issues.

The idea was to establish guidelines that would serve as a foundation for the teaching staff when developing their own activities, providing them with tools that would facilitate the inclusion of sustainability in the teaching guides of their respective subjects. We started with the Bachelor's Degree in Economics, but the work will be extended to the rest of the degrees. We followed [16,17], where the origin, evolution, and main elements that make up the sustainability competency map (SCM) were established. The SCM for the Business Administration degree developed within the EDINSOST1 project [73] was taken as a reference point to elaborate the SCM for the Economics degree. The group had periodic meetings during three months to discuss the content of the map by taking into account the specific characteristics of the degree in Economics. In particular, the specific competences and learning outcomes in sustainability that a graduate in economics should develop were determined.

The development of a competency map is key to the optimal development of ESD in the university system, as it provides a methodology to effectively integrate professional competencies in the curricula. It helps to know which aspects need to be improved and which training students need to acquire in order to advance in the knowledge and application of sustainability competencies. This map is the main element from which teachers identify the knowledge, skills, and attitudes needed to acquire all sustainability competencies.

The result was designed to be a double-entry matrix describing the performance of each competency in the subjects of a degree programme. The rows of the map were defined on the basis of the four competencies related to sustainability established by the CRUE (C1-C4, see Section 2.3), analysing them from the perspective of the three dimensions of sustainability (economic, social, and environmental) and from a holistic point of view. In fact, the $\mathrm{C} 2$ competency was the only one that related in the mapping to the three dimensions of sustainability in addition to the holistic view, while the remaining competencies dealt only with sustainability in a holistic way.

For each dimension, one or more units of competency were defined, as shown in Table 1. The unit of competency is the minimum aggregate of professional competencies, which can be recognised and partially accredited. Each unit of competency was associated with learning outcomes and activities necessary for its acquisition [74]. Expressions such as "competency analysis", "competency certification", "key competencies", and "units of competency" are indicators of a training and an assessment of personal qualities, skills, or knowledge necessary for the exercise of a profession [75]. 
In contrast to competencies, which are general statements about the knowledge, skills, and behaviours to be achieved by learners, learning outcomes are specific statements that, for a given competency, describe exactly what a learner should know or be able to do in a measurable way [76]. A hierarchical approach based on a simplified version of Miller's Pyramid taxonomy [77] was used to integrate competencies into the degree subjects. This defines four domain levels of competency: knowing, knowing how, demonstrating, and doing. Given the subtle difference in many cases, the demonstrating and doing levels were combined into one [17].

Table 1. Sustainability Competency Map of the Bachelor's Degree in Economics.

\begin{tabular}{|c|c|c|c|c|c|}
\hline \multirow{2}{*}{ Comp. } & \multirow{2}{*}{ Dimension } & \multirow{2}{*}{ Competency Unit } & \multicolumn{3}{|c|}{ Domain Level } \\
\hline & & & 1. Know & 2. Know How & 3. Demonstrate and Do \\
\hline \multirow[b]{2}{*}{$\mathrm{C} 1$} & \multirow[b]{2}{*}{$\mathrm{H}$} & $\begin{array}{l}\text { 1. The student has a } \\
\text { state-of-the-art } \\
\text { perspective and an } \\
\text { understanding of } \\
\text { social, economic, and } \\
\text { environmental } \\
\text { problems at local and } \\
\text { global levels. }\end{array}$ & $\begin{array}{l}\text { 1.1.1. Knows the main } \\
\text { causes, consequences, } \\
\text { and solutions } \\
\text { proposed in the } \\
\text { literature regarding } \\
\text { social, economic, and } \\
\text { environmental } \\
\text { problems, both locally } \\
\text { and globally. }\end{array}$ & $\begin{array}{l}\text { 1.2.1 Analyses the } \\
\text { various dimensions of } \\
\text { sustainability when } \\
\text { solving a specific } \\
\text { problem. }\end{array}$ & $\begin{array}{l}\text { 1.3.1. Identifies the main } \\
\text { causes and } \\
\text { consequences of a } \\
\text { problem related to } \\
\text { sustainability, and is } \\
\text { able to relate it to known } \\
\text { problems and previously } \\
\text { applied solutions. }\end{array}$ \\
\hline & & $\begin{array}{l}\text { 2. The student is } \\
\text { critical, creative, and } \\
\text { innovative. They are } \\
\text { able to identify } \\
\text { opportunities to } \\
\text { improve organisations } \\
\text { to contribute to the } \\
\text { development of more } \\
\text { sustainable processes } \\
\text { and products. }\end{array}$ & $\begin{array}{l}\text { 2.1.1. Knows the } \\
\text { concepts and } \\
\text { strategies of } \\
\text { innovation and } \\
\text { creativity applied to } \\
\text { organisations. }\end{array}$ & $\begin{array}{l}\text { 2.2.1. Understands the } \\
\text { methods and techniques } \\
\text { of innovation and idea } \\
\text { generation and knows } \\
\text { how to use them. } \\
\text { 2.2.2. Critically reflects } \\
\text { on new ways of } \\
\text { innovating in } \\
\text { organizations. } \\
\text { 2.2.3. Detects } \\
\text { opportunities to } \\
\text { improve the } \\
\text { sustainability of } \\
\text { products or processes in } \\
\text { the market. }\end{array}$ & $\begin{array}{l}\text { 2.3.1. Brings new ideas } \\
\text { and solutions that allow } \\
\text { organisations to be more } \\
\text { sustainable. }\end{array}$ \\
\hline $\mathrm{C} 2$ & $\mathrm{EV}$ & $\begin{array}{l}\text { 3. The student takes } \\
\text { into account the } \\
\text { environmental impact } \\
\text { of policies, programs, } \\
\text { and projects within } \\
\text { their professional field. }\end{array}$ & $\begin{array}{l}\text { 3.1.1. Knows the } \\
\text { concepts of reusing } \\
\text { and recycling, and } \\
\text { how to reduce the use } \\
\text { of natural resources. } \\
\text { 3.1.2. Is familiar with } \\
\text { the life cycle of } \\
\text { products and the } \\
\text { concept of ecological } \\
\text { footprint, and how to } \\
\text { minimise the } \\
\text { generation of waste. } \\
\text { 3.1.3. Is familiar with } \\
\text { indicators to measure } \\
\text { the environmental } \\
\text { impact of a project in } \\
\text { their professional field. }\end{array}$ & $\begin{array}{l}\text { 3.2.1. Understands the } \\
\text { environmental costs of } \\
\text { economic and business } \\
\text { activities from a local, } \\
\text { national, and global } \\
\text { perspective. } \\
\text { 3.2.2. Is capable of } \\
\text { measuring the } \\
\text { environmental impact of } \\
\text { projects in their } \\
\text { professional field. }\end{array}$ & $\begin{array}{l}\text { 3.3.1. Takes into account } \\
\text { the environmental } \\
\text { effects of the products } \\
\text { and services in the } \\
\text { economic and business } \\
\text { projects in which they } \\
\text { participate. } \\
\text { 3.3.2. Is able to calculate } \\
\text { the ecological footprint } \\
\text { of economic and } \\
\text { business projects. } \\
\text { 3.3.3. Includes in } \\
\text { projects indicators to } \\
\text { measure effects from the } \\
\text { resources used. } \\
\text { 3.3.4. Is able to optimise } \\
\text { the environmental } \\
\text { impact of their } \\
\text { professional activity. }\end{array}$ \\
\hline
\end{tabular}


Table 1. Cont.

\begin{tabular}{|c|c|c|c|c|c|}
\hline \multirow{2}{*}{ Comp. } & \multirow{2}{*}{ Dimension } & \multirow{2}{*}{ Competency Unit } & \multicolumn{3}{|c|}{ Domain Level } \\
\hline & & & 1. Know & 2. Know How & 3. Demonstrate and Do \\
\hline & S & $\begin{array}{l}\text { 4. The student can } \\
\text { identify social } \\
\text { repercussions of } \\
\text { economic and business } \\
\text { decisions and can } \\
\text { propose sustainable } \\
\text { solutions. }\end{array}$ & $\begin{array}{l}\text { 4.1.1. Knows the } \\
\text { problems associated } \\
\text { with social justice, } \\
\text { equity, equality, } \\
\text { diversity, and } \\
\text { transparency in their } \\
\text { professional field. } \\
\text { 4.1.2. Is aware of the } \\
\text { social repercussions of } \\
\text { economic and business } \\
\text { decisions. } \\
\text { 4.1.3. Is familiar with } \\
\text { indicators that } \\
\text { measure inequalities } \\
\text { and describe other } \\
\text { social impacts of a } \\
\text { project in their } \\
\text { professional field. }\end{array}$ & $\begin{array}{l}\text { 4.2.1. Is able to assess } \\
\text { whether a project in } \\
\text { their professional field } \\
\text { contributes to improving } \\
\text { social welfare. } \\
\text { 4.2.2. Understands the } \\
\text { social costs of economic } \\
\text { and business activities } \\
\text { from a local, national, } \\
\text { and global perspective. }\end{array}$ & $\begin{array}{l}\text { 4.3.1. Is capable of } \\
\text { optimising the social } \\
\text { impact of their } \\
\text { professional activity. } \\
\text { 4.3.2. Takes into account } \\
\text { social justice, equity, } \\
\text { equality, diversity, and } \\
\text { transparency in their } \\
\text { decision-making } \\
\text { processes. } \\
\text { 4.3.3. Includes in their } \\
\text { projects indicators to } \\
\text { evaluate impact on } \\
\text { social welfare. }\end{array}$ \\
\hline & EC & $\begin{array}{l}5 . \text { The student is able } \\
\text { to manage } \\
\text { organisations' } \\
\text { material, economic, } \\
\text { and human resources } \\
\text { in a sustainable way. }\end{array}$ & $\begin{array}{l}\text { 5.1.1. Knows the basic } \\
\text { concepts about } \\
\text { sustainable } \\
\text { management of } \\
\text { material, economic, } \\
\text { and human resources } \\
\text { in organisations. } \\
5.1 .2 \text {. Knows the } \\
\text { economic } \\
\text { repercussions of } \\
\text { decisions for } \\
\text { management } \\
\text { (sustainable or not) of } \\
\text { resources. }\end{array}$ & $\begin{array}{l}\text { 5.2.1. Understands the } \\
\text { principles of sustainable } \\
\text { management of material, } \\
\text { economic, and human } \\
\text { resources in } \\
\text { organisations. } \\
\text { 5.2.2. Analyses real cases } \\
\text { of resource management } \\
\text { from an economic } \\
\text { perspective. } \\
5.2 .3 \text {. Understands the } \\
\text { economic consequences } \\
\text { of resource } \\
\text { management. }\end{array}$ & $\begin{array}{l}\text { 5.3.1. Is capable of } \\
\text { making sustainable } \\
\text { economic decisions. } \\
\text { 5.3.2. Is capable of } \\
\text { planning, monitoring, } \\
\text { and evaluating } \\
\text { sustainable policies, } \\
\text { programs, and projects } \\
\text { in their professional } \\
\text { field. } \\
\text { 5.3.3. Applies } \\
\text { sustainable techniques } \\
\text { and indicators for the } \\
\text { management of material, } \\
\text { economic, and human } \\
\text { resources. }\end{array}$ \\
\hline
\end{tabular}

6.1.1. Is familiar with the relationship between social justice, resource reuse, and the economy, both in the private and public spheres.

6. The student is able to design, coordinate, and carry out specific professional actions economic, and surrounding environment.

6.1.2 Knows about new economic approaches that integrate the principles of sustainability (circular economy, social, and solidarity economy, etc.). 6.1.3. Is familiar with the principles of respect for the social, economic, and surrounding environment in their professional field.

\subsubsection{Is capable of} assessing the impact of products and services on society and on the sustainability of the planet.

6.2.2. Knows how to assess the economic viability of a project and whether it is compatible with the environmental and social aspects of sustainability.

6.2.3. Knows how to apply sustainability strategies in production, distribution, consumption, and recycling.
6.3.1. Designs, organises and carries out specific professional actions taking into account the environmental, social, and economic aspects of sustainability.

6.3.2. Includes in their projects indicators that comprehensively evaluate the sustainability of these. 
Table 1. Cont

\begin{tabular}{|c|c|c|c|c|c|}
\hline \multirow{2}{*}{ Comp. } & \multirow{2}{*}{ Dimension } & \multirow{2}{*}{ Competency Unit } & \multicolumn{3}{|c|}{ Domain Level } \\
\hline & & & 1. Know & 2. Know How & 3. Demonstrate and Do \\
\hline C3 & $\mathrm{H}$ & $\begin{array}{l}\text { 7. The student } \\
\text { identifies when the } \\
\text { sustainability of a } \\
\text { policy, program or } \\
\text { project can be } \\
\text { enhanced through } \\
\text { collaborative } \\
\text { community work. He } \\
\text { or she responsibly } \\
\text { performs collaborative } \\
\text { work related to } \\
\text { sustainability. }\end{array}$ & $\begin{array}{l}\text { 7.1.1. Knows the } \\
\text { concept of } \\
\text { collaborative } \\
\text { community work and } \\
\text { its implications for the } \\
\text { transformation of } \\
\text { society. } \\
7.1 .2 \text {. Is familiar with } \\
\text { examples of projects } \\
\text { that have successfully } \\
\text { implemented } \\
\text { community } \\
\text { collaborative work in } \\
\text { their professional field. } \\
\text { 7.1.3. Knows the } \\
\text { collaborative work } \\
\text { tools that can be } \\
\text { applied in their } \\
\text { professional field. }\end{array}$ & $\begin{array}{l}\text { 7.2.1. Is capable of } \\
\text { assessing the social, } \\
\text { environmental, and } \\
\text { economic implications } \\
\text { of a project that includes } \\
\text { collaborative } \\
\text { community work. }\end{array}$ & $\begin{array}{l}\text { 7.3.1. Is able to use } \\
\text { collaborative work tools } \\
\text { in their professional } \\
\text { field. }\end{array}$ \\
\hline $\mathrm{C} 4$ & $\mathrm{H}$ & $\begin{array}{l}\text { 8. The student acts } \\
\text { according to the } \\
\text { deontological } \\
\text { principles related to } \\
\text { sustainability. }\end{array}$ & $\begin{array}{l}\text { 8.1.1. Is familiar with } \\
\text { the deontological } \\
\text { principles related to } \\
\text { sustainability. } \\
8.1 .2 \text {. Is familiar with } \\
\text { the existence of laws } \\
\text { and regulations related } \\
\text { to sustainability in } \\
\text { their professional field. } \\
\text { 8.1.3. Is familiar with } \\
\text { the concept of } \\
\text { corporate social } \\
\text { responsibility (CSR). }\end{array}$ & $\begin{array}{l}\text { 8.2.1. Identifies and } \\
\text { critically analyses the } \\
\text { implications of } \\
\text { deontological principles } \\
\text { related to sustainability } \\
\text { in their professional } \\
\text { field. }\end{array}$ & $\begin{array}{l}\text { 8.3.1. Respects and } \\
\text { upholds the } \\
\text { deontological principles } \\
\text { related to sustainability. } \\
\text { 8.3.2. Is capable of } \\
\text { proposing solutions and } \\
\text { strategies to promote } \\
\text { projects coherent with } \\
\text { the deontological } \\
\text { principles related to } \\
\text { sustainability. }\end{array}$ \\
\hline
\end{tabular}

Adapted from [16,17], C1, C2, C3, C4 CRUE competencies in sustainability in Section 2.3, EV: environmental; S: social; EC: economic; H: holistic.

Once the SCM for the Bachelor's Degree in Economics was determined, the second step of the project was to build a series of open educational resources to cover the different units of competency, bearing in mind the course and the subject of the students to whom they were addressed. This task was approached in groups of two, which involved the design, review, and search in repositories of OERs. Proposed OERs are presented in the following section.

\section{Results}

OERs developed in the context of the aforementioned teaching innovation project constitute the first step in the development and identification of materials that help teachers of the Bachelor's Degree in Economics to integrate sustainability competencies. Most of them are original, but nevertheless some reused other existing OERs according to the corresponding Creative Commons license, following the philosophy of these types of materials. It is important to point out that many of these resources were tested in class by the lecturers involved in the working group and could be used in many of the subjects that make up the economics degree.

Each OER is organised into three sections (identification, design, and additional information), as can be seen in Table 2 . 
Table 2. Structure of the Open Educational Resources for the Bachelor's Degree in Economics.

\begin{tabular}{ll}
\hline & \multicolumn{1}{c}{ Title } \\
\hline & $\mathbf{1 .}$ Identification \\
\hline Competency & \\
Dimension & \\
Competency unit & \\
1. KNOW & \\
2. KNOW HOW & \\
3. DEMONSTRATE + DO & \\
\hline
\end{tabular}

\title{
2. Design
}

\author{
OBJECTIVES \\ STATEMENT \\ STUDENT ACTIVITIES \\ METHODOLOGY
}

3. Additional Information

\author{
REFLECTION QUESTIONS \\ SUPPORTING MATERIALS AND \\ OBSERVATIONS
}

The identification section provides information on the transversal competencies of Sustainability that are worked on from those proposed by CRUE [19]; the dimension of the competency (social, economic, environmental, holistic); the unit of competency of the SCM in Economics; the levels of competency knowing, knowing how, demonstrating and doing); and the Sustainable Development Goals associated with this activity.

The design section details the objectives to be pursued, the statement, the activities to be carried out by the students, and information about the methodology to be used. Finally, the additional information section describes reflection questions to be answered by the learner, material needed for the implementation of the activity, and any other information, such as the subjects in which the activity can be developed.

Particularly relevant is the information on methodological strategies provided in the design block, as the choice of the most appropriate pedagogical methodology to achieve a certain end is fundamental [78]. Several authors [31,79-84] proposed different methodologies to develop sustainability competencies, such as brainstorming, case studies, teamwork, gamification, project and problem-based learning, or the use of videos and puzzles. Lambrechts et al. [85] considered that methodologies for working on sustainability competencies can be of three types: participative and interactive methods (discussion groups, simulation, etc.), action-oriented methods (service learning, etc.), and research methods (problem analysis, case studies, etc.). The following didactic strategies were used in our resources, considered by Tejedor et al. [84] as the most relevant for addressing sustainability competencies at the university level: problem-based learning, service learning, simulation games, case studies, and project-based learning.

The OERs and other information about the innovation project developed by the working group have been published in the DIGITUM repository of the University of Murcia [86]. In particular, the English version of these OERs can be downloaded at hdl.handle.net/10201/111221 (accessed on 30 July 2021). Figure 1 represents an example of OER. 


\begin{tabular}{|c|c|}
\hline \multicolumn{2}{|r|}{ ECONOMIC GROWTH II } \\
\hline \multicolumn{2}{|r|}{ 1. IDENTIFICATION } \\
\hline Competency & $\begin{array}{l}\mathrm{C} 2 \text {. Sustainable use of resources and prevention of negative impacts on the natural and } \\
\text { social environment. }\end{array}$ \\
\hline Dimension & Holistic \\
\hline Competency unit & $3,4,5$ and 6 \\
\hline 1. KNOW & 4.1.2., 5.1.2, 6.1.2. \\
\hline 2. KNOW HOW & $3.2 .1 ., 4.2 .2 ., 5.2 .3$ \\
\hline $\begin{array}{r}\text { 3. DEMONSTRATE + } \\
\text { DO } \\
\end{array}$ & \\
\hline ASSOCIATED SDGS & SDG 4, SDG 8, SDG 10. \\
\hline \multicolumn{2}{|r|}{ 2. DESIGN } \\
\hline OBJECTIVES & $\begin{array}{l}\text { The objective is to make students aware of the implications of economic growth for human } \\
\text { development, as well as other economic issues directly related to the well-being of } \\
\text { citizens. It is also important for them to be aware of other models of economics or less } \\
\text { orthodox theories of growth/development. }\end{array}$ \\
\hline STATEMENT & $\begin{array}{l}\text { The topics of the videos will be about the relationship between the concepts of } \\
\text { growth/development of countries/people and other concepts such as inequality, equity, } \\
\text { poverty, human capital, as well as other less orthodox economic conceptions such as the } \\
\text { economics of the common good and economic degrowth. Other groups can also be } \\
\text { assigned topics related to the SDGs and the role students can play in achieving them (in } \\
\text { the first years) and professionals in the relevant field in the last years. Possible topics for } \\
\text { videos include the following: } \\
\text { - Do we care about equity? } \\
\text { - Growth, inequality and poverty } \\
\text { - Is foreign aid the solution to global poverty? } \\
\text { - Investing in human capital and its relationship to economic growth/development } \\
\text { - The economics of the common good and economic development } \\
\text { - Natural resources, environment and economic growth } \\
\text { - Technological progress and economic growth } \\
\text { - Economic degrowth } \\
\text { - The SDGs and the university: what role students can play in achieving them. } \\
\text { - The Sustainable Development Goals. Key challenges for developed and developing } \\
\text { countries }\end{array}$ \\
\hline $\begin{array}{l}\text { STUDENT } \\
\text { ACTIVITIES }\end{array}$ & $\begin{array}{l}\text { In the making of the video, all the members of the group should be seen at some point. The } \\
\text { video itself should be no less than three minutes and no more than } 10 \text { minutes long. } \\
\text { Alternatively, a standard oral presentation based on a power point type audiovisual file } \\
\text { can be chosen. }\end{array}$ \\
\hline METHODOLOGY & $\begin{array}{l}\text { Case study based on the elaboration of videos by teams of } 3 \text { or } 4 \text { people (depending on the } \\
\text { size of the group) which will later be presented in class. }\end{array}$ \\
\hline \multicolumn{2}{|r|}{ 3.ADDITIONAL INFORMATION } \\
\hline $\begin{array}{r}\text { REFLECTION } \\
\text { QUESTIONS }\end{array}$ & $\begin{array}{l}\text { The questions should be aimed at making them aware of the advantages and disadvantages } \\
\text { of economic growth and to reflect on how they could be solved. }\end{array}$ \\
\hline $\begin{array}{r}\text { SUPPORTING } \\
\text { MATERIALS AND } \\
\text { OBSERVATIONS }\end{array}$ & $\begin{array}{l}\text { Each of the topics would have a document associated to it that can be consulted to facilitate } \\
\text { the process of searching for information on the Internet or in the textbooks themselves. }\end{array}$ \\
\hline
\end{tabular}

Figure 1. Example of Open Educational Resource for the Bachelor's Degree in Economics.

In order to clearly highlight the mean features of the 20 proposed OERs, Table 3 shows their relationship with the four sustainability competencies established by CRUE [19], as well as with the suggested teaching methodologies and the different SDGs covered. 
Table 3. Features of Open Educational Resources for the Bachelor's Degree in Economics.

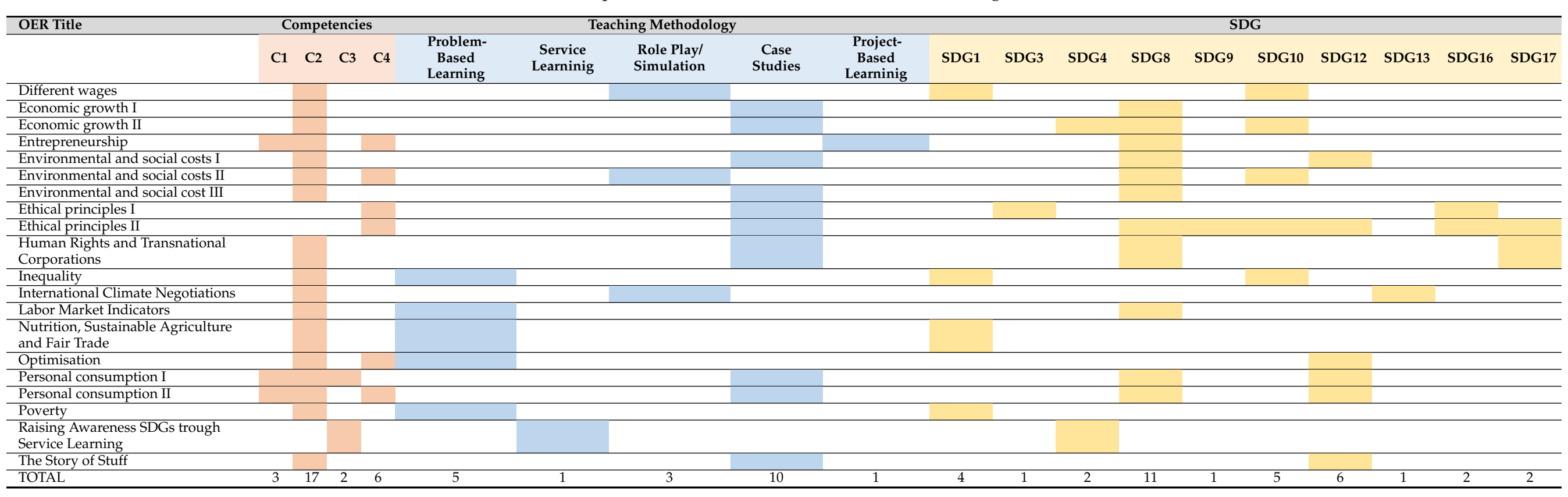




\section{Discussion}

As proposed by UNESCO [87], education for sustainable development should provide students with knowledge, skills, and values to carry out responsible actions with the environment. It should be remembered that Education for Sustainable Development is based on a student-centered pedagogy, so that students should take responsibility for the environmental contents they are taught and be enabled to generate changes towards the construction of a more sustainable world.

The critical role of universities in sustainability have been widely recognised [2,3,19], also with international declarations, as the Graz Declaration on Committing Universities to Sustainable Development [88] or the Rio+20 Higher Education Initiative [89]. However, degrees like Economics remain more market-oriented and profit maximising than sustainability pedagogy [6]. This fact led authors such as Lozano et al. [7] to call for integral implementation of sustainability.

Although many efforts to incorporate sustainable development into HEI have been made $[35-37,90]$, they tended to be compartmentalised [48,49], as they focused on specific domains instead of adopting a holistic view. An additional problem is that university teachers lack adequate training in sustainability and, although much has already been written about this training $[5,9,10,52]$, it is still an unresolved issue in universities [10,55].

In response to these gaps, some lecturers from different departments of the Faculty of Economics and Business at the University of Murcia, trained in curricular sustainability, set up a working group. The intention is to establish the bases that will facilitate the introduction of sustainability for the rest of the teachers in our faculty in the daily practice of the subjects they teach in the different degrees and postgraduate courses.

To this end, the first step was to draw up a sustainability competency map for the Bachelor's Degree in Economics, based on those by EDINSOST for the Degrees in Engineering and Business Administration and Management, adapting the vocabulary to that of the Social Sciences and incorporating new learning outcomes more appropriate to the comprehensive education that economists should achieve.

Based on the competence map, a variety of curricular materials with different degrees of complexity were designed as the result of the effort and experience of the teachers involved in the project. Most of them have been tested in the subjects taught by these teachers, with a magnificent acceptance by the students, and all of them have been discussed in various working meetings. By including different teaching methodologies, considered to be the most appropriate for addressing sustainability competences, these resources facilitate learning to students, who not only acquire the competences of the subject, but also their sustainability consciousness, in line with Boeve-de Pauw et al. [4].

The OERs proposed in this work constituted a diverse and versatile set of materials, which can be exported with confidence to a wide range of subjects in different areas of knowledge without the need for great effort, facilitating the incorporation of sustainability into other degrees, especially in Social Sciences.

Specifically, in the degree in Economics, the syllabi of most subjects are far from being concerned with sustainability, but with the implementation of the activities proposed in the OERs, the teacher will be able to propose practices that bring the student closer to this reality. This practice can facilitate coordination between teachers, both vertically and horizontally, following the same model of how the resources have been developed within the working group. Moreover, as they are published in open access, they can be easily accessed by any teacher interested in incorporating sustainability into their activity. Our conviction is that these materials could contribute to the creation of a learning community where successful experiences can be shared and materials can benefit from the collaboration of other teachers who could add improvements.

Although curricular sustainability is a research topic widely dealt with in the literature, there are very few works that draw up sustainability competence maps for university degrees, and none of them propose training activities with the level of detail of the OERs described in the results of this work. 


\section{Conclusions}

Reduce, recycle, and reuse promotes new business models that impact both economy and society. Therefore, it is necessary to incorporate into current curricula educational practices facilitating the learning of "the knowledge and skills needed to promote sustainable development" [91].

On the basis of this need, we provided a guide to introduce sustainability competencies in the Economics degree by creating a SCM together with a series of learning resources that can help teachers to include sustainability contents in their teaching practice. The practical resources proposed in this paper might serve as a base model to implement sustainability in an easy way. The OERs include the SDG associated with each activity, the objectives to be pursued, the statement, the activities to be carried out by the students, the methodology to be used, the reflection questions to be answered by the learner, the material needed for the implementation of the activity, and any other information.

This proposal can be useful to researchers for the following reasons: first, it presents a basic guide (competency map) to systematically introduce competencies in sustainability in the Degree in Economics, identifying the learning outcomes associated with each competency; and, secondly, it offers a wide range of learning resources to be applied in the classroom by teachers. Although it is focused on the Economics Degree, the map is easily transferable to other universities and faculties and the resources can be used in a wide range of subjects of other social science degrees.

Nevertheless, this work was not absent of limitations. The OERs can be completed with the introduction of new aspects, such as how to evaluate the student's work, and a time estimate (inside and outside the classroom) to complete the proposed activities. They could also include the learning objectives proposed by the UNESCO related to each SDG.

This educational paradigm change we called upon cannot be implemented without the necessary commitment of all professors, because the integration of sustainability in the academic environment implies an additional effort and extra motivation. They not only have to make changes in the contents, but also in the teaching methods, in order to generate training activities that allow the development of competencies in sustainability. In this sense, our contribution can be a starting point to accomplish this. Moreover, given the difficulty of involving teachers in this arduous task, a further line of research would be to analyse how to encourage them to engage in this transformation, not only in the areas of economics and business, but in any other area of knowledge.

In this line, the next action in the working group is to implement a workshop where the resources can be worked out with other staff, in order to facilitate the spread of sustainability competencies among students. Indeed, it is crucial that students become aware that sustainability is a new paradigm in which environmental, social, and economic aspects must be balanced to achieve a development that allows a better quality of life without putting future generations at risk.

Author Contributions: L.M. conceptualization, supervision, writing-review and editing; E.J.S.-A. conceptualization, supervision, writing - review and editing; Ú.F.-M. formal analysis, writingoriginal draft; M.L.-L. formal analysis, writing - original draft; J.V.L.-C. formal analysis, writingoriginal draft; J.L.M.-R. methodology, writing —original draft; P.J.M.-C. methodology, writingoriginal draft; M.C.P.-P. methodology, writing — original draft; M.C.S.-A. formal analysis, writingoriginal draft. All authors have read and agreed to the published version of the manuscript.

Funding: The publication of this paper has been partly funded by EDINSOST internal funds RTI2018-094982-B-I00.

Institutional Review Board Statement: Not applicable.

Informed Consent Statement: Not applicable.

Data Availability Statement: Not applicable.

Acknowledgments: We thank the EDINSOST 2. SDGs, Integración de los Objetivos para el Desarrollo Sostenible en la formación en sostenibilidad de las titulaciones universitarias españolas 
(Integration of the Sustainable Development Goals in sustainability training in Spanish university degrees) for the support provided to use the map of competencies of the Bachelor's Degree in Business Administration.

Conflicts of Interest: The authors declare no conflict of interest.

\section{References}

1. Olsson, D.; Gericke, N. The Adolescent Dip in Students' Sustainability Consciousness: Implications for Education for Sustainable Development. J. Environ. Educ. 2016, 47, 35-51. [CrossRef]

2. Lozano, R.; Ceulemans, K.; Alonso-Almeida, M.; Huisingh, D.; Lozano, F.J.; Waas, T.; Lambrechts, W.; Lukman, R.; Hugé, J. A Review of Commitment and Implementation of Sustainable Development in Higher Education: Results from a Worldwide Survey. J. Clean. Prod. 2015, 108,1-18. [CrossRef]

3. Larrán Jorge, M.; Herrera Madueño, J.; Calzado Cejas, M.Y.; Andrades Peña, F.J. An Approach to the Implementation of Sustainability Practices in Spanish Universities. J. Clean. Prod. 2015, 106, 34-44. [CrossRef]

4. Boeve-de Pauw, J.; Gericke, N.; Olsson, D.; Berglund, T. The Effectiveness of Education for Sustainable Development. Sustainability 2015, 7, 15693-15717. [CrossRef]

5. UNESCO. United Nations Decade of Education for Sustainable Development (2005-2014): Framework for the International Implementation Scheme; UNESCO: Paris, France, 2003. Available online: https:/ / unesdoc.unesco.org/ark:/48223/pf0000131163?posInSet=6\& queryId=88713851-e8ee-46ca-8309-f83b5207d759 (accessed on 30 July 2021).

6. Slocum, S.L.; Dimitrov, D.Y.; Webb, K. The Impact of Neoliberal Academic Policies on Higher Education Tourism Programs: Meeting the 2030 Sustainable Development Goals in the next generation. Tour. Manag. Perspect. 2019, 30, 33-42. [CrossRef]

7. Lozano, R.; Lukman, R.; Lozano, F.J.; Huisingh, D.; Lambrechts, W. Declarations for Sustainability in Higher Education: Becoming Better Leaders, Through Addressing the University System. J. Clean. Prod. 2013, 48, 10-19. [CrossRef]

8. Ferreira, J.-A.; Ryan, L.; Tilbury, D. Mainstreaming education for sustainable development in initial teacher education in Australia: A review of existing professional development models. J. Educ. Teach. 2007, 33, 225-239. [CrossRef]

9. UNESCO. Educating for a Sustainable Future: A Transdisciplinary Vision for Concerted Action; UNESCO: Paris, France, 1997. Available online: https:/ / unesdoc.unesco.org/ark:/48223/pf0000110686 (accessed on 30 July 2021).

10. UNESCO. Guidelines and Recommendations for Reorienting Teacher Education to Address Sustainability; Education for Sustainable Development in Action. UNESCO: Paris, France, 2005. Available online: https://unesdoc.unesco.org/ark:/48223/pf0000143370 (accessed on 30 July 2021).

11. UNESCO. Framework for the Implementation of Education for Sustainable Development (ESD) Beyond 2019. General Conference; 40th Session; UNESCO: París, France, 2019. Available online: https: / unesdoc.unesco.org/ark:/48223/pf0000370215?posInSet=6\& queryId=89666fa5-fcc6-4421-ad8c-2adcbf992c34 (accessed on 21 June 2021).

12. UNESCO. Berlin Declaration on Education for Sustainable Development. UNESCO World Conference on Education for Sustainable Develpmet; UNESCO: Berlin, Germany, 2021. Available online: https://en.unesco.org/sites/default/files/esdfor2030-berlindeclaration-en.pdf (accessed on 30 July 2021).

13. Universidad de Murcia. ODSesiones. Available online: https:/ /www.um.es/web/17odsesiones/ (accessed on 30 July 2021).

14. López López, I.; Bote, M.; Marín Rives, L.; Rubio Bañón, A. Higher Education Institutions as a Transformation Platform under the Sustainable Development Goals Framework. Eur. J. Sustain. Dev. 2019, 8, 306-312. [CrossRef]

15. Universidad de Murcia. AULA 2030: Sostenibilización Curricular. Available online: https://www.um.es/web/17odsesiones/ aula-2030 (accessed on 30 July 2021).

16. Sánchez-Carracedo, F.; Segalàs, J.; Vidal, E.; Martin, C.; Climent, J.; López, D.; Cabré, J. Improving Engineering Educators' Sustainability Competencies by using Competency Maps. The EDINSOST Project. Int. J. Eng. Educ. 2018, 34, 1527-1537.

17. Sánchez-Carracedo, F.; Moreno-Pino, F.M.; Sureda, B.; Antúnez, M.; Gutiérrez, I. A Methodology to Analyse the Presence of Sustainability in Engineering Curricula. Case of Study: Ten Spanish Engineering Degree Curricula. Sustainability 2019, 11, 4553. [CrossRef]

18. Eizaguirre, A.; García-Feijoo, M.; Laka, J.P. Defining Sustainability Core Competencies in Business and Management Studies Based on Multinational Stakeholders' Perceptions. Sustainability 2019, 11, 2303. [CrossRef]

19. CRUE. Guidelines for the Inclusion of Sustainability in the Curriculum; CRUE: Madrid, Spain, 2012. Available online: https: //www.crue.org/wp-content/uploads/2020/02/Directrices_Ingles_Sostenibilidad_Crue2012.pdf (accessed on 21 June 2021).

20. Miao, F.; Mishra, S.; Orr, D.; Janssen, B. Guidelines on the Development of Open Educational Resources Policies; UNESCO and Commonwealth of Learning: Paris, France, 2019. Available online: http:/ /hdl.handle.net/11599/3455 (accessed on 21 June 2021).

21. Sachs, J.D. Achieving the Sustainable Development Goals. J. Int. Bus. Ethics 2015, 8, 53-62.

22. Ministerio de Educación. Estrategia Universidad 2015. In Contribución de las Universidades al Progreso Socioeconómico Español 2010-2015; Secretaría General de Universidades: Madrid, Spain, 2010.

23. Cortese, A.D. The Critical Role of Higher Education in Creating a Sustainable Future. Plan. High. Educ. 2003, 31, 15-22.

24. Leal Filho, W. About the Role of Universities and Their Contribution to Sustainable Development. High Educ. Policy 2011, 24, 427-438. [CrossRef] 
25. UNESCO. Draft International Implementation Scheme for the United Nations Decade of Education for Sustainable Development (20152014); UNESCO: París, France, 2005. Available online: https://unesdoc.unesco.org/ark:/48223/pf0000140372?posInSet=1\& queryId=c2463cb8-defd-49d7-9295-6efd06c7971f (accessed on 21 June 2021).

26. UNESCO. Aichi-Nagoya Declaration on Education for Sustainable Development. In Proceedings of the World Conference on Education for Sustainable Development, Aichi-Nagoya, Japan, 10-12 November 2014. Available online: https:/ / sustainabledevelopment. un.org/content/documents/5859Aichi-Nagoya_Declaration_EN.pdf (accessed on 21 June 2021).

27. UN. Transforming Our World: The 2030 Agenda for Sustainable Development. Resolution adopted by the UN General Assembly on 25 September 2015. Available online: https://www.un.org/ga/search/view_doc.asp?symbol=A/RES/70/1 \&Lang=E (accessed on 21 June 2021).

28. Collazo Expósito, L.M.; Granados Sánchez, J. Implementation of SDGs in University Teaching: A Course for Professional Development of Teachers in Education for Sustainability for a Transformative Action. Sustainability 2020, 12, 8267. [CrossRef]

29. Scott, R.H. Sustainable Curriculum, Sustainable University. eCulture 2009, 2, 122-129.

30. Buckler, C.; Creech, H. Shaping the Future We Want. The United Nations Decade of Education for Sustainable Development (2005-2014); Final Report; UNESCO: París, France, 2014. Available online: http:/ / unesdoc.unesco.org/images/0023/002301/230171e.pdf (accessed on 21 June 2021).

31. Ceulemans, K.; De Prins, M. Teacher's manual and method for SD integration in curricula. J. Clean. Prod. 2010, $18,645-651$. [CrossRef]

32. Lozano, R. Sustainable Development in Higher Education. Incorporation, Assessment and Reporting of Sustainable Development in Higher Education Institutions. MSc Thesis, In Environmental Management Policy. Lund University, Lund, Sweden, 2003. Available online: https:/ / lup.lub.lu.se/student-papers/search/publication/1325193 (accessed on 21 June 2021).

33. SDSN Australia/Pacific. Getting started with the SDGs in Universities: A Guide for Universities, Higher Education Institutions, and the Academic Sector. Sustainable Development Solutions Network (SDSN)_Australia/Pacific: Melbourne, Australia, 2017; Available online: https:/ /ap-unsdsn.org/wp-content/uploads/University-SDG-Guide_web.pdf (accessed on 21 June 2021).

34. SDSN. Accelerating Education for the SDGs in Universities: A Guide for Universities, Colleges and Tertiary and Higher Education Institutions; Sustainable Development Solutions Network (SDSN): New York, NY, USA, 2020. Available online: https: / /irp-cdn.multiscreensite.com/be6d1d56/files/uploaded/accelerating-education-for-the-sdgs-in-unis-web_zZuYLaoZRHK1 L77zAd4n.pdf (accessed on 21 June 2021).

35. Miñano, R.; García Haro, M. Implementando la Agenda 2030 en la Universidad. Casos Inspiradores de Educación para los ODS en las Universidades Españolas. Red Española para el Desarrollo Sostenible (REDS): Madrid, Spain, 2020. Available online: https:/ / reds-sdsn.es/wp-content/uploads /2020/05/Dosier-REDS_Casos-ODS-Univ-2020_web.pdf (accessed on 21 June 2021).

36. Juárez-Nájera, M.; Dieleman, H.; Turpin-Marion, S. Sustainability in Mexican Higher Education: Towards a New Academic and Professional Culture. J. Clean. Prod. 2006, 14, 1028-1038. [CrossRef]

37. Sterling, S. The Future Fit Framework. An Introductory Guide to Teaching and Learning for Sustainability in HE (Guide). J. Educ. Sustain. Dev. 2012, 7, 134-135. [CrossRef]

38. Fernández Morilla, M.; Fuertes Camacho, M.T.; Albareda Tiana, S. Sostenibilización Curricular en la Educación Superior: Propuesta Metodológica. Opción: Revista de Ciencias Humanas y Sociales 2015, 31, 284-304. Available online: https: / www.redalyc. org/pdf/310/31045571018.pdf (accessed on 21 June 2021).

39. Hesselbarth, C.; Schaltegger, S. Educating Change Agents for Sustainability—Learnings from the First Sustainability Management Master of Business Administration. J. Clean. Prod. 2014, 62, 24-36. [CrossRef]

40. López, D.; Sánchez, F.; Vidal, E.; Pegueroles, J.; Alier, M.; Cabré, J.; García, J.; García, H. A Methodology to Introduce Sustainability into the Final Year Project to Foster Sustainable Engineering Projects. In Proceedings of the IEEE Frontiers in Education Conference (FIE) Proceedings, Madrid, Spain, 22-25 October 2014. [CrossRef]

41. Gomera, A.; Antúnez, M.; Villamandos, F. Universities That Learn to Tackle the Challenges of Sustainability: Case Study of the University of Córdoba (Spain). Sustainability 2020, 12, 6614. [CrossRef]

42. Huisingh, D.; Mebratu, D. "Educating the Educators" as a Strategy for Enhancing Education on Cleaner Production. J. Clean. Prod. 2000, 8, 439-442. [CrossRef]

43. Lozano-García, F.J.; Gándara, G.; Perrni, O.; Manzano, M.; Hernández, E.; Huisingh, D. Capacity Building: A Course on Sustainable Development to Educate the Educators. Int. J. Sustain. High. Educ. 2008, 9, 257-281. [CrossRef]

44. Solís-Espallargas, C.; Ruiz-Morales, J.; Limón-Domínguez, D.; Valderrama-Hernández, R. Sustainability in the University: A Study of Its Presence in Curricula, Teachers and Students of Education. Sustainability 2019, 11, 6620. [CrossRef]

45. Leal Filho, W.; Shiel, C.; Paço, A.; Mifsud, M.; Avila, L.V.; Brandli, L.L.; Moltham-Hill, P.; Pace, P.; Azeitero, U.M.; Vargas, V.R.; et al. Sustainable Development Goals and Sustainability Teaching at Universities: Falling Behind or Getting Ahead of the Pack? J. Clean. Prod. 2019, 232, 285-294. [CrossRef]

46. Leal Filho, W.; Salvia, A.L.; Frankenberger, F.; Wall, T.; Hindley, A.; Mifsud, M.; Brandli, L.L.; Will, M. Trends in Scientific Publishing on Sustainability in Higher Education. J. Clean. Prod. 2021, 296, 126569. [CrossRef]

47. Crespo, B.; Míguez-Álvarez, C.; Arce, M.E.; Cuevas, M.; Míguez, J.L. The Sustainable Development Goals: An Experience on Higher Education. Sustainability 2017, 9, 1353. [CrossRef]

48. Azcárate, P.; Navarrete, A.; García, E. Aproximación al Nivel de Inclusión de la Sostenibilidad en los Curricula Universitarios. Profesorado. Rev. Curric. Y Form. Profr. 2012, 16, 105-117. 
49. Leal Filho, W.; Wu, Y.-C.J.; Brandli, L.L.; Avila, L.V.; Azeitero, U.M.; Caeiro, S.; Madruga, L.R.R.G. Identifying and Overcoming Obstacles to the Implementation of Sustainable Development at Universities. J. Integr. Environ. Sci. 2017, 14, 93-108. [CrossRef]

50. Lidgren, A. A Sustainable Course for Higher Education. MSc Thesis, In Environmental Management Policy. Lund University, Lund, Sweden, 2004. Available online: https:/ /lup.lub.lu.se/student-papers/search/publication/1329314 (accessed on 21 June 2021).

51. Lozano, R. Diffusion of Sustainable Development in Universities' Curricula: An Empirical Example from Cardiff University. J. Clean. Prod. 2010, 18, 637-644. [CrossRef]

52. Lozano, R. Incorporation and institutionalization of SD into universities: Breaking through barriers to change. J. Clean. Prod. 2006, 14, 787-796. [CrossRef]

53. UE4SD. Leading Practice Publication. Professional Development of University Educators on Education for Sustainable Development in European Countries; University Educators for Sustainable Development (UE4SD): Prague, Checz Republic, 2015.

54. Barth, M.; Godemann, J.; Rieckmann, M.; Stoltenberg, U. Developing Key Competencies for Sustainable Development in Higher Education. Int. J. Sustain. High. Educ. 2007, 8, 416-430. [CrossRef]

55. UNESCO. Education for Sustainable Development Goals: Learning Objectives; UNESCO: Paris, France, 2017; Available online: https:/ / unesdoc.unesco.org/ark:/48223/pf0000247444 (accessed on 21 June 2021).

56. Benito Olalla, C.; Merino, M. Competences for Sustainability in Undergraduate Business Studies: A Content Analysis of Value-Based Course Syllabi in Spanish Universities. Int. J. Educ. Manag. 2019, 17, 239-253. [CrossRef]

57. Delors, J. Learning: The Treasure Within. Report to UNESCO of the International Commission on Education for the Twenty-first Century. 1996. Available online: https:/ / www.eccnetwork.net/resources/learning (accessed on 21 June 2021).

58. UNESCO. Education for All by 2015: Will We Make It? UNESCO: Paris, France, 2008. Available online: https:/ / unesdoc.unesco. org/ark:/48223/pf0000154743 (accessed on 21 June 2021).

59. Blok, V.; Gremmen, B.; Wesselink, R. Dealing with the Wicked Problem of Sustainability: The Role of Individual Virtuous Competence. Bus. Prof. Ethics J. 2016, 34, 297-327. [CrossRef]

60. Lans, T.; Blok, V.; Wesselink, R. Learning Apart and Together: Towards an Integrated Competence Framework for Sustainable Entrepreneurship in Higher Education. J. Clean. Prod. 2014, 62, 37-47. [CrossRef]

61. Barrón, A.; Ferrer-Balas, D.; Navarrete Salvador, A. Sostenibilización Curricular en las Universidades Españolas: ¿Ha llegado la hora de actuar? R. Eur. Edc. 2010, 7, 388-399. Available online: http://hdl.handle.net/10498/9877 (accessed on 30 July 2021). [CrossRef]

62. Ministerio de Educación. Real Decreto 1027/2011, de 15 de Julio, por el que se Establece el Marco Español de Cualificaciones para la Educación Superior. BOE 2011, 185, 87912-87918, Madrid, España, 3 de agosto de 2011. Available online: https: / /www.boe.es/eli/es/rd/2011/07/15/1027 (accessed on 21 June 2021).

63. CHEA. Accreditation and Student Learning Outcomes: Perspectives from Accrediting Organizations; Council for Higher Education Accreditation (CHEA): Washington, DC, USA, 2019. Available online: https:/ /www.chea.org/sites/default/files/pdf/ Accreditation\%20and\%20Student\%20Learning\%20Outcomes\%20-\%20Final.pdf (accessed on 21 June 2021).

64. Hylen, J. Giving Knowledge for Free: The Emergence of Open Educational Resources; Centre for Educational Research and Innovation (CERI), OECD: París, France, 2007; Available online: https:/ / www.oecd.org/education/ceri/givingknowledgeforfreetheemergenceofopeneducationalresources.htm (accessed on 21 June 2021).

65. Downes, S. Models for Sustainable Open Educational Resources. Interdiscip. J. Knowl. Learn. Objects 2007, 3, 29-44. [CrossRef]

66. Hilton, J., III; Wiley, D.; Stein, J.; Johnson, A. The four 'R's of openness and ALMS analysis: Frameworks for open educational resources. Open Learn. 2010, 25, 37-44. [CrossRef]

67. Wiley, D.; Bliss, T.J.; McEwen, M. Open Educational Resources: A Review of the Literature. In Handbook of Research on Educational Communications and Technology; Spector, J., Merrill, M., Elen, J., Bishop, M., Eds.; Springer: New York, NY, USA, $2014 ;$ pp. 781-789.

68. Butcher, N. A Basic Guide to Open Educational Resources (OER); Commonwealth of Learning \& UNESCO: París, France, 2011. Available online: https:/ / unesdoc.unesco.org/ark:/48223/pf0000215804 (accessed on 21 June 2021).

69. Berti, M. Open Educational Resources in Higher Education. Issues Trends Educ. Technol. 2018, 6, 4-15. [CrossRef]

70. McKerlich, R.; Ives, C.; McGreal, R. Measuring Use and Creation of Open Educational Resources in Higher Education. Int. Rev. Res. Open Distance Learn. 2013, 14, 90-103. [CrossRef]

71. Lane, A. Open Education and the Sustainable Development Goals: Making Change Happen. J. Learn. Dev. 2017, 4, 275-286.

72. Sclater, N. Open Educational Resources: Motivations, Logistics and Sustainability. In Content Management for E-Learning; Ferrer, N.F., Alonso, J.M., Eds.; Springer: New York, NY, USA, 2010; pp. 179-193.

73. Segalàs Coral, J.; Sanchéz Carracedo, F. El Proyecto EDINSOST. Formación en las Universidades Españolas de Profesionales como Agentes de Cambio para Afrontar los Retos de la Sociedad. Revista de Educación Ambiental y Sostenibilidad 2019, 1, 1204. [CrossRef]

74. Ministerio de Educación y Formación Profesional (Gobierno de España). Glosario de Términos. Available online: https: //www.educacionyfp.gob.es/fpadistancia/en/comunes/glosario.html (accessed on 21 June 2021).

75. Botello, C.M.; Chiang, M. Competencias y Educación Superior. Un Estudio Empírico. Horiz. Educ. 2007, $12,23-35$.

76. Hartel, R.W.; Foegeding, E.A. Learning: Objectives, Competencies, or Outcomes? J. Food Sci. Educ. 2004, 3, 69-70. [CrossRef]

77. Miller, G.E. The assessment of clinical skills/competence/performance. Acad. Med. 1990, 65, S63-S67. [CrossRef] [PubMed]

78. Seatter, C.S.; Ceulemans, K. Teaching Sustainability in Higher Education: Pedagogical Styles that Make a Difference. Can. J. High. Educ. 2017, 47, 47-70. [CrossRef] 
79. Cotton, D.; Winter, J. It's Not Just Bits of Paper and Light Bulbs: A Review of Sustainability Pedagogies and Their Potential for Use in Higher Education. In Sustainability Education: Perspectives and Practice across Higher Education; Jones, P., Selby, D., Sterling, S., Eds.; Earthscan: London, UK; New York, NY, USA, 2010.

80. Hopkinson, P.; James, P. Practical Pedagogy for Embedding ESD in Science, Technology, Engineering and Mathematics Curricula. Int. J. Sustain. High. Educ. 2010, 11, 365-379. [CrossRef]

81. Sprain, L.; Timpson, W.M. Pedagogy for Sustainability Science: Case-Based Approaches for Interdisciplinary Instruction. Environ. Commun. A J. Nat. Cult. 2012, 6, 532-550. [CrossRef]

82. Dicheva, D.; Dichev, C.; Agre, G.; Angelova, G. Gamification in Education: A Systematic Mapping Study. Educ. Technol. Soc. 2015, $18,75-88$.

83. Fletcher, R. Gaming Conservation: Nature 2.0 Confronts Nature-deficit Disorder. Geoforum 2017, 79, 153-162. [CrossRef]

84. Tejedor, G.; Segalás, J.; Barrón, A.; Fernández Morilla, M.; Fuertes, M.T.; Ruíz Morales, J.; Hernández, A. Didactic Strategies to Promote Competencies in Sustainability. Sustainability 2019, 11, 2086. [CrossRef]

85. Lambrechts, W.; Mulà, I.; Ceulemans, K.; Molderez, I.; Gaeremynck, V. The Integration of Competences for Sustainable Development in Higher Education: An Analysis of Bachelor Programs in Management. J. Clean. Prod. 2013, 48, 65-73. [CrossRef]

86. Molera, L.; Faura-Martinez, U.; Lafuente-Lechuga, M.; Llinares-Ciscar, J.V.; Marín-Rives, J.L.; Martin-Castejon, P.J.; MartinezCarrasco Pleite, F.; Puigcerver-Penñalver, M.C.; Sánchez-Alcazar, E.J.; Sánchez-Anton, M.C. Informe Proyecto Piloto. Elaboración de Mapas de Sostenibilidad, Contenidos Transversales Básicos en Sostenibilidad e Instrumentos para la Sostenibilización Curricular en la Facultad de Economióa y Empresa. Universidad de Murcia: Murcia, Spain, 2020; Available online: http: / / hdl.handle.net/10201/98451 (accessed on 21 June 2021).

87. UNESCO. Unpacking Sustainable Development Goal 4: Education 2030 Guide; UNESCO: Paris, France, 2016. Available online: https:/ / unesdoc.unesco.org/ark:/48223/pf0000246300 (accessed on 30 July 2021).

88. Graz, U.; Copernicus, O. TUG. Graz Declaration on Committing Universities to Sustainable Development; UNDESD: Graz, Austria, 2005. Available online: https://www.iau-hesd.net/sites/default/files/documents/2005_-_graz_declaration_on_committing_ universities_to_sustainable_development_fr.pdf (accessed on 30 July 2021).

89. UN. Rio+ 20 Higher Education Sustainable Initiative; UN Conference on Sustainable Development (UNCSD): Rio de Janeiro, Brazil, 2012. Available online: http://www.unesco.org/new/en/rio-20/single-view/news/universities_mobilize_for_green_societies_ higher_education/ (accessed on 30 July 2021).

90. Lidstone, L.; Wright, T.; Sherren, K. An Analysis of Canadian STARS-rated Higher Education Sustainability Policies. Environ. Dev. Sustain. 2015, 17, 259-278. [CrossRef]

91. UNESCO. Mainstreaming SDG4-Education 2030 in Sector-wide Policy and Planning: Technical Guidelines for UNESCO Field Offices; UNESCO: Paris, France, 2016. Available online: https://unesdoc.unesco.org/ark:/48223/pf0000246475 (accessed on 30 July 2021). 